\title{
Editorial
}

doi: 10.35366/103306

\section{El desafío de la educación en ortopedia}

\author{
The challenge of orthopedic education \\ Salcido-Reyna MV* \\ Hospital ISSSTECALI, Mexicali, Baja California.
}

La educación se define como el proceso de socialización del individuo, mediante el cual adquiere los conocimientos; implica también la generación de una consciencia cultural y conductual.

El desafío de la educación de los ortopedistas es más que un aprendizaje académico, el desarrollo de competencias se ha convertido en la primera línea de batalla; sin embargo, ésta debe ir más allá, enfocada no sólo a crear médicos capaces, sino confiables, empáticos, con ética social y con valores. Si bien muchas de estas características del ser humano son aprendidas durante las primeras etapas de la vida, es compromiso nuestro, sus antecesores, más que ser profesores, ser guías que permitan el arraigo profundo de estas cualidades, convirtiendo al tutor en un modelo inspiracional.

Este desafío se divide en tres áreas: la académica, que involucra desarrollar las competencias y destrezas diagnósticas, terapéuticas y quirúrgicas. La emocional, implica conservar nuestra esencia como persona, la dignidad y el equilibrio afectivo, permitiendo desarrollar la personalidad y madurar en un ambiente sano y de confianza; la considero la más compleja, ya que es el resultado del equilibrio de las otras dos; y finalmente, la social, entendiendo que enfrentamos en el mundo una situación difícil donde las acciones del cirujano ortopedista impactan la salud y el bienestar de la población; se requiere la integración diaria de la ética, del cuidado enfocado a ver al individuo y no a las grandes masas y emprender acciones preventivas.

Como expresó Malala Yousafzai en su discurso ante el Banco Mundial: «Si se quiere acabar la guerra con otra guerra nunca se alcanzará la paz. El dinero gastado en tanques, en armas y soldados se debe gastar en libros, lápices, escuelas y profesores»; la educación se necesita para vencer al terrorismo, pero no sólo al terrorismo que causa un ataque estremecedor con bombas y disparos, también es terrorismo el silencio estremecedor de la indiferencia humana por la salud, por la mejoría o por el bienestar de una sociedad, esta educación va más allá de los libros, va vestida con el ejemplo y con el respeto.

La voz tiene poder, nuestras acciones como médicos ortopedistas y como tutores tienen poder a través del ejemplo de nuestro crecimiento, podemos fomentar valores como el respeto a nuestra profesión, a la vida, a la dignidad humana $\mathrm{y}$, de la misma manera, hacer que los nuevos ortopedistas desarrollen ese compromiso de continuar con la educación de las siguientes generaciones, ésta es la única manera de vencer el terrorismo de la indiferencia humana y lograr el desafío de la educación en la ortopedia.

* Coordinadora de Enseñaza e Investigación del Hospital ISSSTECALI, Mexicali, Baja California.

Correspondencia:

Marlene Vanessa Salcido-Reyna

E-mail: drasalcidoreyna@gmail.com 